\title{
Library Use at Pahlavi University
}

\begin{abstract}
In this study of library use at Pahlavi University, Shiraz, Iran, stratified sampling was employed for distribution of questionnaires to students and systematic sampling for interviews with faculty. They were supplemented by interviews with library staff and personal observations. Analysis of data supported the hypotheses that (1) students of Pahlavi University do not make full use of library resources and (2) faculty members do not promote use of the library by students. Recommendations include: (1) appointment of a reference librarian, first in the Mulla Sadra library of the College of Arts and Sciences and then in other libraries, and (2) a required course in the use of books and libraries.
\end{abstract}

$\mathbf{T}$ HERE ARE APPROXIMATELY one hundred institutions of higher education in Iran, including eight universities. ${ }^{1}$ Pahlavi University in Shiraz is unique in a number of ways. Formerly the University of Shiraz, it was transformed in the $1960 \mathrm{~s}$ into a major university in the national system, modeled along American lines and with a master plan for future development prepared by consultants from the University of Pennsylvania.

English is the principal language of instruction, a situation not found in other universities. Entering undergraduates must take intensive courses in English during the first two years so that they can attend classes conducted in English, use Englishlanguage books, and write examinations in English. Graduate students must demonstrate proficiency in English or accept conditional admission and a limited course load until proficiency is achieved. The university has six colleges and a graduate school. Enrollment in the academic year 1976-77 was $4,934 .^{2}$

The major colleges are Arts and Sciences, Medicine, Engineering, and Agriculture. Smaller and newer are the colleges of Dentistry and Veterinary Medicine. The School

Ali A. Emdad is a doctoral student in library science at Case Western Reserve University. A. Robert Rogers is acting dean, School of Library Science, Kent State University. In 1976-77 he was visiting professor of library science, Pahlavi University. of Graduate Studies, like its counterpart on most American campuses, embraces departments in several disciplines, though principally in such fields as physics, chemistry, and biology. The Department of Library Science (opened in 1974) is one of the few graduate programs outside the physical sciences. In addition to the colleges, there is a program in nursing, and there are some specialized endeavors, such as the Asian Institute. $^{3}$

Eight of the ten libraries associated with Pahlavi University were examined in the study. (Only the Technical School of Electronics and the University High School were excluded.) Total library resources include about 240,000 books and 12,000 volumes of periodicals. The Mulla Sadra library of the College of Arts and Sciences is the largest, with 110,000 volumes in English and other Western languages, 40,000 volumes in Farsi, and 1,100 current periodical titles.

The College of Medicine library is next in size of holdings, with over 18,000 volumes of books in English, French, German, Farsi, and Arabic, together with 1,115 current periodicals in these same languages. It is located in badly overcrowded quarters in a classroom building but is heavily used and headed by a medical librarian renowned throughout the Middle East.

The College of Engineering library occupies spacious new quarters in a multipurpose building. It has a good collection of 
abstracts, indexes, and patent literature, as well as books and periodicals on various phases of engineering. The College of $\mathrm{Ag}$ riculture library has a handsome building of its own on the Bajgah Campus, about fifteen miles north of the city.

All of these libraries are headed by professionals with master's degrees or postmaster's certificates from accredited library schools in the United States. The libraries serving students in dentistry, veterinary medicine, and nursing are somewhat smaller. The Asian Institute library has a specialized collection of Orientalia.

In most developing countries, the system of education in elementary and secondary schools does not promote library use. The majority of the schools have very small libraries, which do not meet their educational needs, and students who graduate from these schools come to the university with no knowledge of the use of library resources.

By and large, students still go through the motions of attending some required courses, memorize notes they have taken from lectures, read textbooks, and prepare for examinations. ${ }^{4}$

In the present survey, an attempt was made to find out to what extent students of Pahlavi University make use of university libraries, what their reading interests are, and what deficiencies they have found in the libraries they use.

The study was guided by the following hypotheses: (1) Students at Pahlavi University do not make full use of library resources, and (2) faculty members do not promote the use of the library by students. ${ }^{5}$

\section{REVIEW OF THE LITERATURE}

A brief review of existing research will help to place the present effort in an international framework. The pioneer study by Branscomb found that major responsibility for student use or lack of use of the college library lay with the faculty. ${ }^{6}$ This view was later confirmed by Shores and by Knapp, who found widespread lack of understanding among faculty about what a library really is and limited student experience with libraries. ${ }^{7}$ Research in Britain by Mann revealed that undergraduates are able to complete their courses of study with rela- tively little use of books. ${ }^{8}$

Meanwhile, Rzasa and Moriarty found that the users of American university libraries are far from homogeneous in their reasons for library visits and that library programs must be tailored to the needs of at least three distinct client groups: undergraduates, graduate students, and faculty. ${ }^{9}$

Lynch doubted that it is possible to reach students without faculty cooperation and believed that this approach could work only for those few students who are willing to learn about the library. ${ }^{10}$ However, Griffin and Clarke reported that communication between teachers and librarians about library use is gradually expanding and expressed hope that in the future imaginative programs, new techniques, and equipment would enable better library service to be given. ${ }^{11}$ An optimistic note was also sounded by Umapathy who found that 83 percent of the students in a master's class in Mysore, India, expressed a desire to receive instruction in the use of the library. ${ }^{12}$

Katebi surveyed the reading habits of students at the University of Tehran. She found that students do not look at "reading" as a way of acquiring knowledge or developing character, primarily because of deficiencies in the educational system. She noted that public libraries in Iran are increasing, but they do not function properly, and that little attention has been paid to libraries as educational centers. She concluded that employing professionally qualified and experienced librarians can encourage people, and particularly youngsters, to read and to use libraries. ${ }^{13}$

In a study carried out by the newspaper, Rastakhiz, it was found that most Iranian students do not have any interest in reading. In response to the question, "Why do you not use the library?" they stated that they are not familiar with the library and have not been directed or encouraged to use it. Faculty members noted that the library does not have the books they need, and so they do not use it but buy their own books. The study concluded by emphasizing the role of the teaching staff in encouraging students in the use of libraries. ${ }^{14}$

\section{METHODOLOGY}

A questionnaire containing thirty-nine 
questions was distributed to 10 percent of the students in each college by year of study and in the School of Graduate Studies, using the technique of stratified random sampling. Systematic sampling was used for faculty interviews, which were guided by a list of thirteen questions. More than 80 percent of the 593 student questionnaires were returned, and 440 usable responses were analyzed by computer using SPSS. Data were gathered during the second month of the winter semester, 1976-77. Student and faculty responses were supplemented by interviews with library staff and personal observations.

The first set of questions provided some information about the students, their reading habits, and interests. The next part dealt with library use. This included data on libraries used most for borrowing and for study, as well as the number of books each student had on loan from the libraries. Then the students' problems in the use of libraries and their opinions about the library collections in their subjects were considered. The next part dealt with guidance students received from the faculty in the use of the library, reading lists, and books introduced in class. Students were also given the opportunity to comment about the library, guidance from the faculty, etc. These comments formed the final part of the data analyzed.

\section{ChaRACTERISTICS OF STUdENTS}

Of the total number of respondents who indicated their sex, 53 percent were male and 47 percent were female. Only 8 percent were married. Eighty percent were in the conventional four-year undergraduate programs. Six percent were enrolled in the School of Graduate Studies, and the remainder were in professional schools, such as the College of Medicine.

Over three quarters ( 77.9 percent) of the students reported between two and five hours of leisure time per day, with the largest cluster ( 24.3 percent) at three hours.

Students were asked about the ways they use their leisure time. Twenty-two percent watch movies or television or listen to the radio. Sixteen percent read nontextbooks. Four percent engage in sports and two percent in the arts.
Although only 16 percent of the students said they read nontextbooks in response to the previous question, 89 percent answered the question about type of leisure reading. Thirty-nine percent identified "books" as the type of material they were most interested in reading, and 23 percent mentioned newspapers. Twenty-seven percent said they read books, magazines, and newspapers in their leisure time.

Students were further asked to specify their areas of reading interest. Seventeen percent said they were interested in the social sciences, 16 percent in technical and scientific subjects, 14 percent in literature, and 10 percent in fiction.

Eighty percent answered the question "How many nontextbooks do you own?" Thirty-one percent claimed to possess one to ten books. Nine percent indicated they own 100 to 500 books.

Twenty-two percent said they were not interested in reading. Seventy-eight percent mentioned lack of time, too many assignments, or examinations as barriers to reading nontextbooks.

\section{STUDENT USE OF UNIVERSITY LIBRARIES}

A question about the amount of time spent in the library was asked to find out the differences, if any, between students in different years of study. Fifty-six percent of the respondents spend one to three hours per day in a library. The proportion increases from 47 percent in the first year to 72 percent in the fifth year and beyond (mostly medical and graduate students).

Students in the first through fourth years usually take eleven to twenty credits, but students in the fifth year and beyond usually take only six to ten credits.

Although most respondents spend one to three hours per day in a library, much of the time is spent reading their own textbooks and notes. Students were asked to give their reasons for not using library materials. Fifty percent said there was no need to use library resources. Twenty-four percent indicated unfamiliarity with the card catalog and different parts of the library, and 12 percent cited classwork and preparation for examinations. Disorganization of the library was also mentioned as a barrier.

Thirty-three percent of the respondents 
use the Mulla Sadra library of the College of Arts and Sciences for private study. Seventeen percent use the new reserve reading hall (opened as an annex to Mulla Sadra in the fall of 1976), 15 percent use Engineering, 10 percent use Medicine, and 9 percent use Agriculture.

Nearly one-seventh of the respondents do not use any library for borrowing. Mulla Sadra receives the heaviest use at 37 percent, probably because all students in their first two years at Pahlavi must take general courses in the College of Arts and Sciences. The proportion of respondents who do not use any library for borrowing is highest in the first year and lowest in the eighth year. (One-third of all first-year students do not use any library for book borrowing.)

Each student was asked how many books he or she currently had on loan from the libraries. Well over one-third said they had no books on loan. Among first-year students this figure was 50 percent. By contrast, only 15 percent of the respondents in the School of Graduate Studies had no books on loan, and 11 percent reported more than ten books.

Students were asked about library holdings in their fields. Twenty-three percent did not comment. Twenty-six percent said "poor" or "very poor," while 38 percent said "fairly good" and 13 percent "very good." Graduate students were most critical of the library collections, and medical students were most satisfied.

Term papers are very common in American universities and usually require library use. Since Pahlavi University is modeled on the American university pattern, it was thought desirable to find out if term papers are required in the courses offered in the various colleges. Students were asked about the number of term papers (or other work that required the use of the library) to be written in the 1976-77 winter semester for the courses they were taking.

Half the respondents were not required to write any term papers -79 percent of first-year, 75 percent of second-year, 50 percent of third-year, and 40 percent of fourth-year students. For those in the fifth year and beyond, the proportion dropped to less than 25 percent. Only 8 percent of the students in the School of Graduate Studies were not required to write any term papers.

\section{STUDENTS' KNOWLEDGE OF THE LIBRARIES}

Students were asked about the procedure they follow for obtaining a book in the library to see if they were familiar with the library and also to check their previous responses. Sixty-nine percent of respondents indicated the card catalog as the first place they would check, 20 percent mentioned the circulation desk, and 11 percent said they would go directly to the shelves. The proportion who would go first to the card catalog rose to 96 percent for students in the School of Graduate Studies. Among first-year students, 33 percent would go to the circulation desk and ask for the book or the way to find it on the shelves, and 18 percent would go directly to the shelves. For the second year and beyond, a much lower percentage would go to the circulation desk.

In the Mulla Sadra library the majority of the questions brought to the reference desk were about how to find library materials and how to use the card catalog.

To check on responses to the previous question, students were asked whether or not they had used the card catalog. Seventy-five percent answered in the affirmative. By comparing this reply to the previous one, it can be concluded that the responses are reasonably true, because 69 percent of the students said earlier that they would go first to the card catalog. More than 90 percent of the students in the fourth year and beyond had used the card catalog.

Students were asked about difficulties in obtaining books or periodical articles for their term papers or project work. The distribution of degrees of difficulty was as follows: some, $\mathbf{4 5}$ percent; fairly large amount, 18 percent; great difficulty, 15 percent. Thus, 78 percent experienced at least some degree of difficulty. The second- and fifthyear students had the highest percentages of those who reported difficulties in using the libraries. Students coming from other universities to begin graduate study at Pahlavi could explain the fifth-year figures, but the second-year figures are puzzling.

In an analysis by colleges, Engineering, Arts and Sciences, and Agriculture had very 
high "problem scores" compared with other colleges. There were many comments from Arts and Sciences students about the problem of obtaining the books and periodicals they need. Mention was made of the length of faculty loan periods and the problems of overdues.

Student use of books and libraries in academic institutions depends largely on faculty attitudes toward the library, its role in the educational process, and the way faculty promote student use of the library by their own example as well as their teaching methods. Several questions were asked to find out the situation in this regard as the students see it.

Sixty-three percent of the students reported that few or none of their teachers mention or recommend books in class. The proportions declined from 93 percent in the first year to 27.5 percent in the fourth year and 16 percent in the School of Graduate Studies.

Although 67 percent of the students indicated that few or none of their lecturers give reading lists, most students who did receive them were satisfied with them. Students in the fourth year and beyond reacted most favorably to the reading lists. By colleges it was found that students in the School of Graduate Studies and in the College of Medicine were most satisfied, while students in Engineering and Veterinary Medicine were most critical. Some students did report, however, that books on the lists were not available in libraries or the university bookstore.

In most of the general courses the lecturers do not give reading lists. In informal interviews with students at different levels of study, it was found that students prefer taking notes to reading books. Students remarked that examination questions are usually chosen from a certain text, or class notes, and so they think it is not necessary to read any other material. A typical comment came from a third-year student in engineering who said that there was no need to buy books because the class notes were very comprehensive.

All students were asked whether they received any guidance in the use of the library from their teachers, and 77 percent reported receiving no training. The per- centages of those not receiving guidance were higher for the first four years than for the fifth year and beyond. Students were also asked to give their opinion about any briefing they did receive from the faculty in the use of the library. On the whole, they were satisfied, with 72 percent rating the guidance as "fairly good," 21 percent as "very good," and only 7 percent as "poor."

More than half the students did not make comments or suggestions. All those who made long and comprehensive comments were in the School of Graduate Studies. Those improvements that received most attention were: increasing the number of new books (both Farsi and English), more library facilities, and the need for library instruction.

\section{DATA GATHERED FROM}

FACULTY MEMBERS

The first few questions were asked to get some background information about the faculty. Then a group of questions dealt with the guidance they give to students in using the library, providing reading lists, and introducing books in class. Finally, they were invited to make comments.

The majority of the faculty members have been teaching at Pahlavi University for two or three years. Some of them have more than one specialization and are teaching only in their areas of specialization. Approximately 59 percent use the Mulla Sadra library and the other 41 percent the libraries of their colleges. Books are the most used materials, except for the faculty in the sciences and applied sciences who reported using journals most.

Seventy-eight percent of the faculty have published one to three articles in the past two years, and 15 percent have published four or more. Only 7 percent had no publications.

Twenty percent of the respondents indicated they do not spend any time in the library, and 39 percent said they spend less than one hour per week there. Nearly half of them taught two courses in the second semester of 1976-77.

Fifty-nine percent of the respondents said that the courses they teach require term papers, and 71 percent said that they introduce books in class. Only 46 percent give reading lists to their students. 
More than half of the faculty respondents did not make any additional comments. Others commented about the library they use. All of them said that students do not read books other than the assigned textbooks, even when they are given reading lists. The respondents also remarked that students use libraries as places for reviewing their class notes and that only a few students read books other than textbooks.

\section{DATA FROM STAFF at Circulation DESKS}

It was thought desirable to gather information from the staff at the circulation desks in the various libraries, and the four that follow were selected as typical: Mulla Sadra, Engineering, Dentistry, and Nemazi Hospital.

The only library that provided some printed information was Engineering. Approximately 275 users come each day, and about 2,830 volumes circulate per month. About twenty-five readers use the periodicals section each day. Many students ask for help at the circulation desk.

The library at Nemazi Hospital is small, mostly used by nursing and medical students. It provides SDI service to doctors. Students using this library ask mostly informational (rather than directional) questions. New students receive some guidance in the use of the library. About fifteen to twenty books circulate each day, and the number of daily users ranges from twenty to thirty.

The College of Dentistry library has about twenty visitors per day and circulates from twenty to thirty books daily. The staff give guidance in library use to students and limited reference service to both faculty and students.

The Mulla Sadra library has the highest circulation, with about 200 books per day. The number of Farsi books circulated increases sharply in the summer. Most of the questions students ask at the circulation desk are about how to use the card catalog and how to find books on the shelves. At the beginning of each semester, the number of questions increases. A reference desk that gives service to students and faculty has been functioning in the Mulla Sadra library for the past two years, staffed by graduate students in the Department of Library Science. A record of questions asked at the reference desk shows that the majority deal with use of library resources and location of books on shelves.

\section{PERSONAL OBSERVATIONS}

In order to recheck some of the points that were asked in questionnaires and interviews, personal observations were carried out in all libraries at different times. In almost all libraries, most of the students were reading their notebooks and discussing points with one another. This observation is consistent with remarks by students working at the reference desk and staff at the circulation desks.

The number of students who wanted some sort of guidance from the circulation desk was higher in Mulla Sadra than in other libraries, possibly because of the fact that all students receive their first two years of instruction in the College of Arts and Sciences.

Only the College of Agriculture library (housed in a handsome new building of its own) has adequate physical facilities. The College of Engineering library, though new and attractive, was found to be overcrowded at times. The most serious overcrowding occurred in the College of Medicine and in the Mulla Sadra library.

Members of the faculty were conspicuous by their absence during the periods of observation.

\section{CONCLUSIONS AND RECOMMENDATIONS}

The study began with two hypotheses: (1) Students at Pahlavi University do not make full use of library resources, and (2) faculty members do not promote the use of the library by students.

As far as the first hypothesis is concerned, the statistical analysis shows that the majority of students do not use library resources for various reasons. Fifty percent of the students mentioned that there was no need to use library materials. Most students find textbooks and class notes to be sufficient.

It is clear that many undergraduates are not good readers and thus do not make optimal use of the library resources provided for them.

The second hypothesis was that faculty 
members do not promote student use of the library. The majority of the students reported that few or none or their professors give them reading lists or guidance in the use of the library. But interviews with faculty members revealed that well over half say they introduce books in class, and only slightly less than half give reading lists to their students.

There is a conflict between the testimony of the students and that of the faculty. This contradiction makes it difficult to say clearly that the evidence supports the second hypothesis. Perhaps it could be said that the hypothesis is largely, though not completely, supported.

Key results of the data gathering are summarized below:

1. The majority of students have difficulty in locating books and articles in the library.

2. The majority of students say they do not receive reading lists from members of the faculty.

3. More than two-thirds of the students claim not to receive any guidance from the faculty in use of the library.

4. A large proportion (77.9 percent) of the students have two to five hours of leisure time per day.

5. Only 16 percent of the students devote their leisure time to reading nontextbooks.

6 . About 40 percent of the students prefer to read books, rather than magazines or newspapers, in their leisure time.

7. Mulla Sadra library is most heavily used for borrowing books.

8. A slight majority of the students have a favorable opinion of the library collections in their subjects.

9. Library use by students shows an increase as the year of study increases.

The following recommendations are made to promote library use by students:

1. A full-time reference librarian should be employed to provide reference service and organize a reference department. This can be done first in Mulla Sadra library and later in other libraries.

2. As all entering students at Pahlavi University have to take English courses, the reference librarians should, in cooperation with the faculty in the Department of Foreign Languages, develop a program that would provide the students with a basic orientation to the use of libraries.

3. Library tours, manuals, guides, directories, orientation, and invitational lectures are helpful ways of introducing the library and library resources to the students and should be organized in a planned way at regular intervals.

4. A course in the use of books and libraries, such as the one currently offered on an elective basis in the College of Arts and Sciences, should be required of every student entering the university. The student must take this course during the first semester of study.

5. A browsing room or area with a collection of recreational reading, including magazines, should be organized. Modern methods of attractive display should be used in that section making it a welcome place for all students.

6. Librarians should work more with the faculty and with their support increase student use of libraries.

7. Concentration on collection building has been a library policy in the past. At the present time the educational function of the library and the need for more reader service should be recognized and emphasized by the library staff.

8. Libraries should have a pleasant atmosphere and sponsor art exhibitions, book exhibitions, and other educational and recreational activities to promote library consciousness among students.

\section{REFERENCES}

1. For general background see: Institute for Research and Planning in Science and Education, The System of Higher Education in Iran (Tehran: Institute, 1972), passim. For recent statistics consult: Iran Almanac and Book of Facts (16th ed.; Tehran: Echo of Iran, 1977), passim. For an overview of academic libraries see: Abazar Sepehri, "Academic Libraries in
Iran: A Critical Appraisal," Unesco Bulletin for Libraries 32:87-91 (March-April 1978).

2. Details of enrollment by colleges and years of study may be found in: Pahlavi University, Office of Admissions and Records, "Statistics of Students of Pahlavi University in the First Semester of the Academic Year 2535-2536 According to Fields of Study," Pahlavi Uni- 
versity Bulletin 2535 (1977), p.4, 166.

3. For further details consult: Parvin Kujoory, A Guide for Newcomers to the College of Arts and Sciences (Shiraz: Pahlavi University, 1976).

4. Rahmat Fattahi, "Comments on University Libraries," Kayhan, Nov. 4, 1976, p.23.

5. A detailed exposition of the methodology and the results may be found in the thesis on which this article is based: Ali A. Emdad, "A Survey of Library Utilization by the Students of Pahlavi University" (master's thesis, Pahlavi University, 1977).

6. Harvie Branscomb, Teaching with Books: A Study of College Libraries (Hamden, Conn.: Shoe String Press, 1964), p.37.

7. Louis Shores, "The Undergraduate and His Library," in John David Marshall, ed., The Library in the University: The University of Tennessee Library Lectures, 1949-1966 (Hamden, Conn.: Shoe String Press, 1967), p. 203; Patricia B. Knapp, College Teaching and the College Library (Chicago: American Library Assn., 1959).
8. Pater H. Mann, Students and Books (London: Routledge and Kegan Paul, 1974).

9. Philip V. Rzasa and John H. Moriarty, "The Types and Needs of Academic Library Users: A Case Study of 6,568 Responses," College d Research Libraries 31:403-9 (Nov. 1970).

10. Mary Jo Lynch, "Trials, Tactics and Timing: Some Thoughts about Library Instruction Programs," in Sul H. Lee, ed., A Challenge for Academic Libraries (Ann Arbor: Pierian Press, 1973), p. 8.

11. Lloyd W. Griffin and Jack A. Clarke, "Orientation and Instruction in the Use of the University Library: A Case Study," College $b$ Research Libraries 33:467-72 (Nov. 1972).

12. K. Setty Umapathy, "Post-Graduate Students' Knowledge of Information Sources," in Librarianship: Change or Status Quo? (New Delhi: Vikas, 1977), p.87-94.

13. Sedigheh Katebi, "Survey of the Reading Habits and Interests of Students" (in Persian; M.L.S. thesis, University of Tehran, 1972).

14. Editorial, Rastakhiz, March 20, 1977, p.8. 